\title{
"Combating crime in the banking sector as a method for ensuring its stability (evidence from Ukraine)"
}

\begin{tabular}{|c|c|}
\hline \multirow{5}{*}{ AUTHORS } & Alyona Klochko (D) http://orcid.org/0000-0002-9596-6814 \\
\hline & Oksana Kvasha (Dttps://orcid.org/0000-0002-9832-6070 \\
\hline & Zoia Zahynei (D) https://orcid.org/0000-0002-8679-124X \\
\hline & Mykola Logvinenko (D http://orcid.org/0000-0002-5231-3610 \\
\hline & Mykola Kurylo iD https://orcid.org/0000-0003-1496-134X \\
\hline ARTICLE INFO & $\begin{array}{l}\text { Alyona Klochko, Oksana Kvasha, Zoia Zahynei, Mykola Logvinenko and Mykola } \\
\text { Kurylo (2020). Combating crime in the banking sector as a method for ensuring } \\
\text { its stability (evidence from Ukraine). Banks and Bank Systems, 15(1), 143-157. } \\
\text { doi:10.21511/bbs.15(1).2020.14 }\end{array}$ \\
\hline DOI & http://dx.doi.org/10.21511/bbs.15(1).2020.14 \\
\hline RELEASED ON & Wednesday, 25 March 2020 \\
\hline RECEIVED ON & Tuesday, 14 January 2020 \\
\hline \multirow[t]{2}{*}{ ACCEPTED ON } & Wednesday, 12 February 2020 \\
\hline & $(\mathrm{oc}) \mathrm{EY}$ \\
\hline LICENSE & $\begin{array}{l}\text { This work is licensed under a Creative Commons Attribution } 4.0 \text { International } \\
\text { License }\end{array}$ \\
\hline JOURNAL & "Banks and Bank Systems" \\
\hline ISSN PRINT & $1816-7403$ \\
\hline ISSN ONLINE & $1991-7074$ \\
\hline PUBLISHER & LLC "Consulting Publishing Company "Business Perspectives" \\
\hline FOUNDER & LLC "Consulting Publishing Company "Business Perspectives" \\
\hline
\end{tabular}

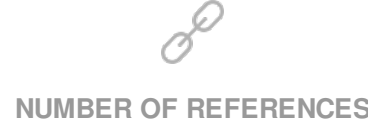

28

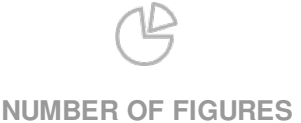

2
$-=-$
$-=-$

NUMBER OF TABLES

0

(C) The author(s) 2022. This publication is an open access article. 


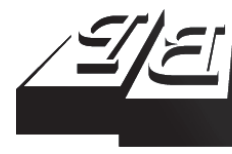

\section{BUSINESS PERSPECTIVES}

()

LLC "CPC "Business Perspectives"

Hryhorii Skovoroda lane, 10, Sumy, 40022, Ukraine

www.businessperspectives.org
Received on: $14^{\text {th }}$ of January, 2020 Accepted on: $12^{\text {th }}$ of February, 2020 Published on: $25^{\text {th }}$ of March, 2020

(C) Alyona Klochko, Mykola Kurylo, Oksana Kvasha, Zoia Zahynei, Mykola Logvinenko, 2020

Alyona Klochko, Ph.D. in Law, Associate Professor, Sumy National Agrarian University, Head of the Chair of International Relations, Ukraine.

Mykola Kurylo, Doctor of Law, Professor, First Vice-Rector, Sumy National Agrarian University, Ukraine.

Oksana Kvasha, Doctor of Law, Professor, V. M. Koretsky Institute of State and Law of the National Academy of Sciences of Ukraine, Ukraine.

Zoia Zahynei, Doctor of Law, Associate Professor, Head of the Department of Prosecutors Training in the Sphere of Corruption Counteraction, Prosecutors' Training Institute of the National Prosecution Academy of Ukraine, Ukraine.

Mykola Logvinenko, Ph.D. in Law, Associate Professor, EducationalScientific Institute of Law of Sumy State University, Ukraine.
Alyona Klochko (Ukraine), Mykola Kurylo (Ukraine), Oksana Kvasha (Ukraine), Zoia Zahynei (Ukraine), Mykola Logvinenko (Ukraine)

\section{COMBATING CRIME}

IN THE BANKING SECTOR

AS A METHOD FOR ENSURING ITS STABILITY (EVIDENCE FROM UKRAINE)

\begin{abstract}
An effective system for combating banking crimes can ensure the stability of the Ukrainian banking sector. Developing such a system requires an analysis of public policy institutional instruments to counter threats to the banking system stability. The article proposes the crime counteraction concept for the Ukrainian banking system based on the analysis of scientific articles dealing with the issue, relevant provisions of legal acts and on the study of functions of law enforcement agencies, individual executive bodies, central public authorities, state collegial bodies, territorial NBU departments, Ukrainian banks and their branches, the Deposit Guarantee Fund, international institutions, and bank clients.

It has been established that the stability of the Ukrainian banking system can be ensured by effective interaction of all actors in combating crime in the banking business. Overlapping of their functions and some conflict rules negatively affect ensuring the banking system stability by entities engaged in banking crime counteraction. Therefore, an algorithm of cooperation between relevant counteraction entities should be developed and reflected in the Banking and Financial Security Strategy on the legislative level. Optimization of statistical reporting on crime in the Ukrainian banking sector in a more informative format requires data on both individual types of banking crimes and on the persons who commit them. As part of the work of the National Bank of Ukraine's Public Council, it is necessary to organize regional public councils and ensure cooperation between bank clients and local banking institutions. It is assumed that the development of effective mechanisms for protecting rights and legitimate interests of depositors and creditors, as well as combating criminalization in the banking sector will be the main functions of these regional public councils. The relevant innovations require amendments to the Regulation on the NBU Public Council.
\end{abstract}

\section{Keywords}

economy, banks, criminality, subjects, prevention, system, improvement

\section{JEL Classification K14, E58, E59}

\section{INTRODUCTION}

Meeting the Ukrainian economy needs for financial and credit resources, to organize the activities of payment, deposit and credit systems, is one of the priority tasks of the banking system. Changes in the country's socio-economic conditions and the world crisis negatively affect its functioning; and it is impossible to counteract the negative impact of global phenomena on the functioning of the Ukrainian banking system. However, protecting the banking system from unlawful interference is an important task for entities involved in combating crime in the banking sector, whose activities are not always effective due to the lack of cooperation in certain areas, optimal algorithms for individual crime prevention entities and a unified classification of bank crimes, gaps in the legislation, etc. Despite the obvious criminal 
situation in the Ukrainian banking sector, few, if any, studies have been carried out on criminal and legal protection of banking activities (Klochko, Kurilo, \& Zapara, 2017).

The economy of Ukraine requires an effective banking system, which generally affects the socio-political stability of the country. Banking is an important investment tool that has an immediate impact on economic development. The financial and economic downturn and high-level criminalization in the banking sector of Ukraine have exacerbated problems facing the banking sector. A fragile banking system impedes the development of entrepreneurship, contributes to a decrease in the production level, thus leading to economic imbalance in all areas of the national economy.

Preventive measures in the banking business in Ukraine not only protect these public relations from dangerous encroachments, but also potentially unstable members of society from further moral degradation.

The purpose of the article is to analyze the institutional instruments of state policy for combating threats to banking stability in Ukraine.

\section{LITERATURE REVIEW}

Ensuring the stability of the banking system and its dependence on different external and internal risks have been repeatedly considered by theoreticians and practitioners around the globe. In particular, Neiman noted that the banking sector is a key employer in the country. There is no single solution to address the effects of the housing crisis and widespread turmoil in the financial markets (Neiman, 2009). Hartmann, Straetmans, and de Vries studied the reports from the United States and the euro area comparing the banking system stability of the two largest economies in the world (Hartmann, Straetmans, \& de Vries, 2005). According to Banking Supervision in Hong Kong, banking institutions are closely related to people's everyday activities and lives. Paying bills, drawing salaries, buying houses, getting loans and accumulating savings are all related to transactions with banking institutions. Doing business also depends on the banking system to meet financial needs or to settle any transactions. Banking institutions are closely related. Therefore, the problems faced by one bank can quickly spread to other banking institutions. The stability of the banking system is supported by public trust. Any collapse of banking operations can affect the whole society. Thus, banking stability is a determining factor in minimizing the social and extensive economic impact that may result from the problems in the industry (HKMA, 2003). According to the European Semester: Thematic Factsheet, bank loans satisfy the basic needs of households, and EU member states should take appropriate measures to limit potential risks in the banking system (European Commission, 2016).

Banking system stability (BSS) is able to maintain reliability and balance for a long time, and is also determined by the proportionality, robustness and reliability of its structural elements. The banking system is considered sound if it is profitable and sustainable, consistent with national legislation and risk management principles established by the Basel Committee on Banking Supervision. According to Liovochkin, Oparin, and Fedosov, the banking system is stable if it:

1) is still able to perform these important functions even in the face of external shocks or increased imbalances;

2) contributes to efficient allocation of financial resources in space and time;

3) allows assessing, allocating and managing financial risks (Liovochkin, Oparin, \& Fedosov, 2011).

Criminalization of the Ukrainian banking sector is a risk that adversely affects the stability of the banking system, undermines the activities of banking institutions and leads to a loss of bank customers' confidence in both the regulatory bodies and the banking system as a whole. One can highlight some features 
of crimes in banking operations, namely: the amount of damage caused to the bank or its customers may be large; high crime latency; the use of banking institutions to transfer proceeds of crime to other countries; "cooperation" between the bank management and criminal organizations, etc. (Kurylo, Klochko, Timchenko, \& Gulyk, 2017).

Crime prevention is a combination of legislative, economic, ideological, social, educational, cultural and other actions aimed at mitigating, eliminating or neutralizing the conditions and causes of crime. Preventive measures can be taken at the national, regional or local level or in the relevant sector of the economy, in an institution or an organization.

According to Kovalenko (2016), crime prevention is a complex multi-level system consisting of subjects, objects and preventive measures. The subject of crime prevention can be any authority, organization, private person that performs at least one of the following functions in this activity: organization, coordination, implementation or direct participation in the process (Kovalenko, 2016). Depending on the goals, objectives, and functional responsibilities, the subjects engaged in combating crime can be divided into two groups:

1) the subjects of combating crime, operating at the national level; and

2) special entities of combating crime.

The special anti-crime entities include bodies specially created to combat crime, that is, those operating within the framework of criminal justice, and bodies that perform other functions, that is, operate outside of criminal justice. Likhnovitsky proposes to divide the subjects of combating crime by the functionality criterion into the following groups:

1) bodies and organizations for which prevention of crime and crime elements is included or should be included in the main tasks and functions (Ministry of Internal Affairs, Security Service of Ukraine, Prosecutor General's Office, Court, specialized public organizations);

2) bodies (organizations) that manage these types of activities and create their manage- ment systems (local government; public authorities and management);

3) institutions and organizations whose powers are not aimed at combating crime and the elements of crime, but their activities affect preventive measures related to the causal complex of crime and individual crimes (administration of enterprises, institutions and organizations, social welfare bodies, education and culture authorities, etc.) (Likhnovitsky, 2014).

The statistical method used in the study made it possible to establish general statistical patterns of crime in the banking sector. Observation, grouping and analysis of numerous banking crimes directly depend on the state registration of data and their systematic accounting. However, this process proved to be problematic because of the lack of statistical information on crimes before 2011 in the public domain. Moreover, the reliability of the available statistical information is relative, and its analysis is complicated by a range of the following factors:

1) a certain percentage of hidden crimes in the banking sector;

2) lack of unified reporting on crime in banking in Ukraine.

Using the synergetic method of cognition, banking crimes were explored as a self-organizing system. The analysis of the state and development of the economy, budget and tax systems helped to identify shortcomings and gaps in the protection of the Ukrainian banking from crime.

Thus, quantitative indicators of crime in the banking business are identified, summarized and analyzed from three available sources of crime indicators in banking. These are:

1) annual reports of the Deposit Guarantee Fund (data for 2013-2018);

2) annual statistical reporting of the Prosecutor General's Office of Ukraine (four types of statistical reporting); and

3) reports of the State Financial Monitoring Service of Ukraine. An analysis of the cur- 
rent legislation and many scientific sources allowed formulating the concept of crimes in the field of banking.

Banking crimes are understood as the system of deliberate socially dangerous actions provided for in the Criminal Code of Ukraine (CC), which are committed by executives or other bank officials, or any persons associated with the bank, or any persons responsible for conducting banking transactions, or any other employees of banking institutions, as well as any persons not related to the banking sector and aimed at appropriating funds of banking institutions or banking clients during banking operations or when using them.

Figure 1 provides statistical indicators of the total number of banking crimes in Ukraine (Articles 200, 209, 218-1, 220-1, 220-2, 222, 231, 232 of the Criminal Code of Ukraine) over the period 2014-2018.

Despite fluctuations in the quantitative indicators of banking crimes in Ukraine, there is a general tendency to a slight decrease in the period from 2015 to 2017 and a rapid increase in the number of crimes committed in 2018, as evidenced by the slope of the direct alignment of the dynamic series. The absolute data deviation in 2018 , compared to the beginning of the reporting period, amounted to 505 crimes. In general, the relative deviation of such crimes in the banking sector is $72.1 \%$ in 2018. Such disappointing statistics prompts to identify areas for combating crime in the banking sector in Ukraine, considering the reform of the Ukrainian banking system and its adaptation to international standards. In particular, one of the main areas of the Ukrainian banking system integration in the EU and measures for its implementation should be to ensure its stability and increase competitiveness in the international banking services markets. This will be facilitated by the introduction of a mechanism to prevent and minimize risks that may be caused to the national banking system due to its criminalization.

\section{BASIC PROVISIONS}

To find out the main directions of ensuring the stability of the Ukrainian banking system, it is necessary to determine the range of entities that counteract crime in the banking sector. So far, these entities include:

1) law enforcement agencies (the National Police of Ukraine, the Prosecutor General's Office of Ukraine, the Security Service of Ukraine, the

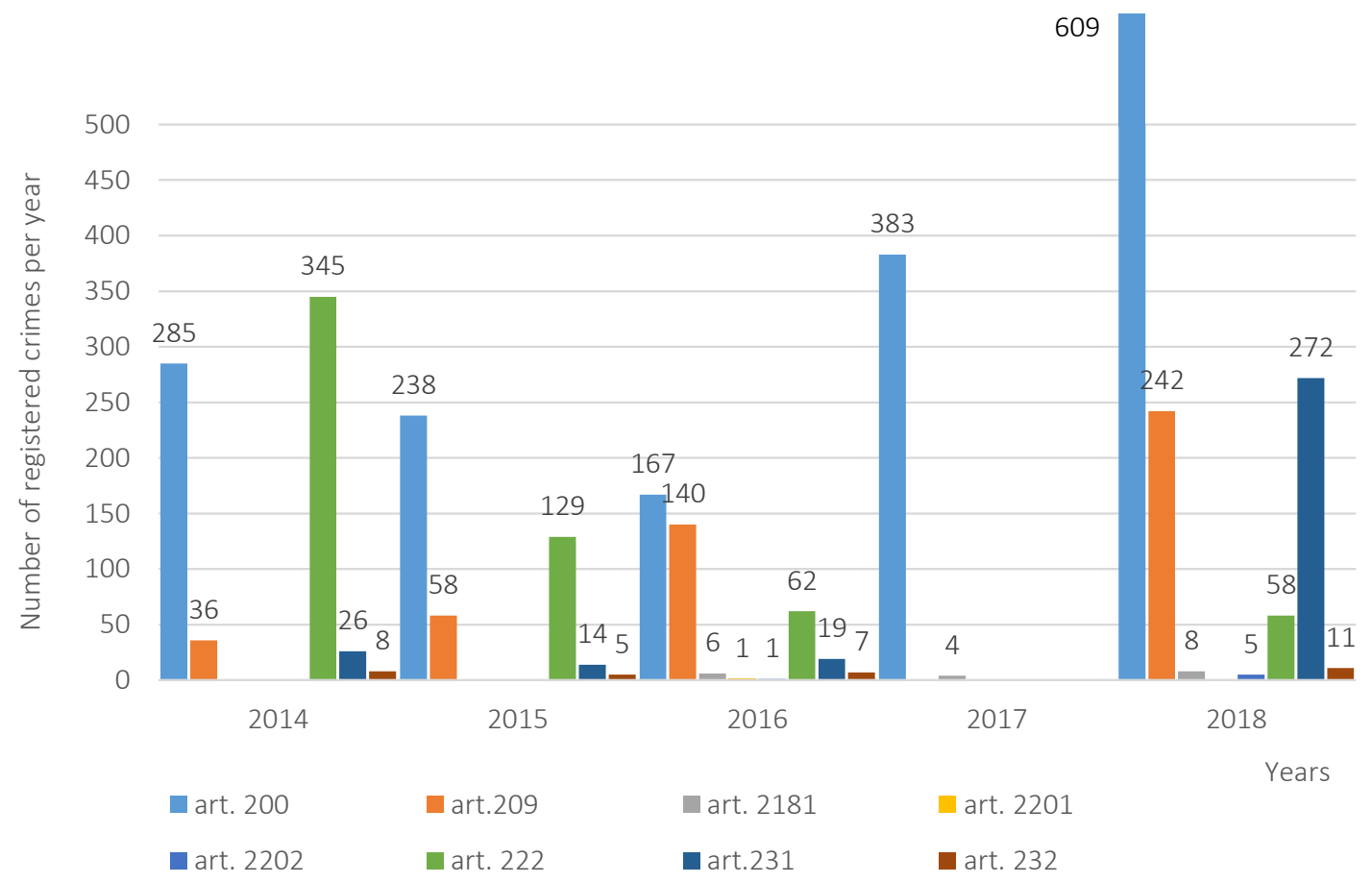

Figure 1. Banking crime statistics in Ukraine for the period of 2014-2018 
National Anti-Corruption Bureau of Ukraine, and the State Bureau of Investigation);

2) executive authorities (the Ministry of Internal Affairs of Ukraine, the State Fiscal Service of Ukraine, and the State Financial Monitoring Service of Ukraine);

3) central public authorities (the Ministry of Finance of Ukraine, the National Bank of Ukraine);

4) state collegial and advisory bodies (the National Financial Services Commission, the NBU Public Council);

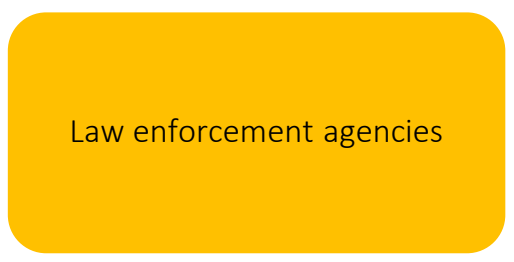

National Police

Prosecutor General's Office of Ukraine

Security Service of Ukraine

National Anti-Corruption Bureau of Ukraine

State Bureau of Investigation

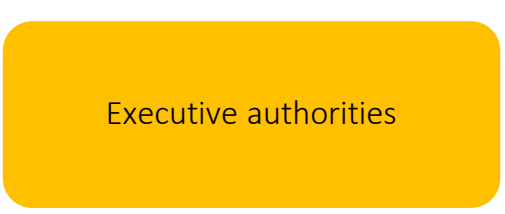

Central government bodies

State collegial bodies

NBU territorial offices, Ukraine banks and their branches

Deposit Guarantee Fund

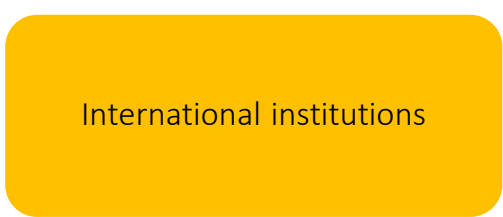

Citizens

Ministry of Internal Affairs of Ukraine

State Fiscal Service of Ukraine

State Financial Monitoring Service of Ukraine

Ministry of Finance of Ukraine

National Bank of Ukraine Markets institutions, security services of banking institutions

Offense investigation Department

Basel Institute on Governance

International Monetary Fund

World Bank

Banking services users
5) territorial departments of the NBU, banks of Ukraine and their branches (top management (administration), as well as officials and employees of banking institutions, security services of banking institutions);

6) Deposit Guarantee Fund (DGF) (the DGF's Offense Investigation Department);

7) international institutions;

8) individual bank customers.

Figure 2 outlines entities engaged in combating crime in banking.

National Commission for State Regulation of Financial Services

Top management, officials and employees of banking

European Bank for Reconstruction and Development

Figure 2. Entities of combating crime in banking in Ukraine 
The activities of the Prosecutor General's Office and the National Police of Ukraine in the prevention of crime in the banking sector can be interrelated. The media began to discuss 2018 cases in the Volyn region, when prosecutors sent indictments against ten criminal groups (including those involved in banking and economic activity) to the court. It was about illegal circulation of excisable goods, counterfeiting of foreign currency, organization of illegal movement of people across the state border, illicit circulation of psychotropic substances, etc.

Subdivisions of the Office for Combating Drug Crime of the National Police's Main Directorate in the region identified three organized groups of ten people who were engaged in the systematic illegal production, transportation, and storage of psychotropic substances, in particular amphetamine, for sale in the region. Funds derived from the illicit trafficking of psychotropic substances were credited to bank accounts for subsequent use for crime purposes. By joint efforts of the police and prosecutor's office of the region, it was proved that members of criminal groups managed to launder UAH 10597.83 (Prosecutor's Office of the Volyn region, 2018).

The current Law of Ukraine 'On Prosecution' dated October 14, 2014 (Verkhovna Rada of Ukraine, 2015), like the previous Law of November 5, 1991, authorizes the prosecutor to coordinate the activities of law enforcement agencies in the field of crime prevention. Only the General Prosecutor's Office of Ukraine, heads of regional and local prosecutor's offices, their first deputies and the deputies by the distribution of duties are authorized to coordinate the activities of law enforcement agencies in the field of crime prevention (Article 25, Part 2, of the Law on Prosecution dated October 14, 2014).

The Security Service of Ukraine (SSU) (special body with law enforcement functions) identifies banking crimes that may threaten the national security of Ukraine. For example, in June 2019, the SSU found out appropriations of funds allocated by the NBU for refinancing. Representatives of a private joint-stock company appropriated the amount of funds in excess of USD 17 million and then brought it to offshore accounts. The SSU found that a sham contract was concluded with an offshore company for the supply of equipment to a foreign company. Thus, the funds were in the account of a non-resident company, and foreign exchange controls and fiscal service checks were evaded through a controlled commercial bank, which was in the process of liquidation. This crime led to state losses of more than UAH 436 million (Security Service of Ukraine, 2019).

The National Anti-Corruption Bureau of Ukraine notes in its report for the first half of 2019 that it is an effective pre-trial investigation body that identifies corruption schemes and holds top officials accountable. Thus, in the banking sector, the NABU's subordinates are: the Chairman of the NBU, his deputies, and members of the NBU's Board. However, the list of such persons is expanding by other officials. For example, on September 27, 2019, Oleg S., the former people's deputy, was given a notice of suspicion of embezzling Oschadbank's USD 20 million. The crime was committed under a corruption scheme. The actions of the suspect were determined such that they complied with Part 5 of Art. 191, Part 3 of Art. 27, Part 3 of Art. 209, and Part 1 of Art. 366 of the Criminal Code of Ukraine (Report of the National Anti-Corruption Bureau of Ukraine, 2019). NABU focused its work on constant interaction, partnership with public and high communication efficiency.

The State Bureau of Investigations (SBI) is a new law enforcement agency set up to combat crimes committed by top executives. In particular, the SBI's duty is to counteract, detect, reveal and investigate crimes committed by high-ranking officials, including the President of Ukraine, whose term of office has been terminated, a member of the Cabinet of Ministers of Ukraine, a member of the National Council on Television and Radio Broadcasting, a Chairman of the State Committee for Television and Radio Broadcasting of Ukraine, a member of the National Commission for State Regulation of Financial Services Markets, the National Securities and Stock Market Commission, the Antimonopoly Committee of Ukraine, the Chairman of the State Property Fund of Ukraine, a peoples' deputy of Ukraine, the Prosecutor General of Ukraine, his first deputy and deputy, the Director of the National Anti-Corruption 
Bureau of Ukraine, the Chairman of the National Bank of Ukraine, his first deputy and deputy, and other selected senior officials (State Bureau of Investigations of Ukraine, n. d.).

For example, in 2019, investigators from the central SBI unit sent notifications of suspicion to some senior officials involved in crimes committed in the banking sector in Ukraine. In particular, they uncovered a criminal scheme of embezzlement and misappropriation of bank funds, in which former leaders and the direct owner of the bank, as well as a people's deputy of Ukraine, can participate.

As a result of a preliminary investigation, it was found that during 2007-2014, an offshore company opened credit lines in foreign banks. Collateral agreements were concluded with banking institutions for more than USD 113 million. Due to non-fulfillment of contractual obligations, foreign banks lost the pledged property of the offshore company in 2015. After the Ukrainian bank was declared insolvent, it was immediately written off from the offshore company. The amount of damage is estimated at UAH 2.52 billion.

On August 5, 2019, SBI investigators gave notice of suspicion to one of the bank's chief executives and an ex-deputy chairman of the board. In July 2019 , another ex-deputy chairman of the bank was convicted to a pre-trial detention for two months or, alternatively, on bail in the amount of UAH 232 million. In addition, other four top bank officials, including those on the international wanted list, were given notification of suspicion.

The actions of the highest official were determined as complying with Part 2 of Art. 205 of the Criminal Code of Ukraine and Part 5 of Art. 191 of the Criminal Code of Ukraine. The actions of the chief executive were defined as complying with Part 5 of Art. 191 of the Criminal Code of Ukraine (State Bureau of Investigations of Ukraine, n.d.).

The State Fiscal Service (SFS) is actively fighting the theft of banks' assets through the 'conversion centers'. Their timely detection and liquidation reduce the risk of committing crime in the banking sector. This agency focuses on the need to reduce the number of frauds among bank ex- ecutives, which led to disposal of liquid assets and deliberately bringing banks to insolvency, as well as to preventing theft of deposits made by bank depositors, for example, by financing non-existent (specially created and controlled) companies with an overstated value of the pledged property.

In the typology of legalization (laundering) of proceeds from crime, the State Financial Monitoring Service of Ukraine (SFMS) determines the need to investigate criminal schemes and develop the most effective directions for detecting them to combat crimes, taking into account the experience of law enforcement and financial authorities of Ukraine and other countries (SFMS, 2009). To prevent and detect such activities, the agency conducts on-site inspections, takes operational measures, analyzes reports, including those of banking institutions, investigates financial transactions and exercises currency control.

Fraud prevention (Article 190 of the Criminal Code), misappropriation, embezzlement or seizure of another's property by abuse of office (Article 191 of the Criminal Code), business crimes (Article 222 of the Criminal Code), service crimes (Article 364,365 CC), illegal actions with the transfer of documents, payment cards and other means of access to bank accounts, equipment for their production (Article 200 of the Criminal Code), official forgery (Article 366 of the Criminal Code) may be closely related to the preventing and counteracting the legalization (laundering) of proceeds, which is part of the SFMS' tasks.

The Ministry of Internal Affairs (MIA) occupies a central place in the system of special subjects of combating crime in the banking sector in Ukraine and affects a wide range of preventive actions. The activity of the Ministry of Internal Affairs in crime prevention is comprehensive; in particular, it is aimed at creating a safe environment for citizens. Activities of the bodies of the Ministry of Internal Affairs are focused on the public needs, aimed at prompt and competent response to events and emergencies threatening the public or personal safety of citizens. Strengthening the rule of law in the country, combating crime, and improving the methods and means of preventive actions of the bodies of the Ministry of Internal Affairs on combating crime are the priority tasks 
of the Ministry of Internal Affairs of Ukraine. The above provisions are important to prevent any crime. Knowledge of the basic forms and methods of preventive activities of the Ministry of Internal Affairs allows for proper organization of fight against crime in the Ukrainian banking sector.

Kashpur calls financial monitoring one of the most effective measures to prevent crime in banking. Thus, legal relations in the field of financial monitoring in terms of counteracting the legalization (laundering) of proceeds of crime are systemic. These relations include financial law relations, criminal law relations, administrative law relations, international law relations, economic theory (unshadowing the economy, gray economy), etc. Financial monitoring is an important part of the system of combating the legalization of criminal funds. The interaction between the elements of this system will contribute to the effective counteraction to the legalization of proceeds of crime (Kashpur, 2018).

Goralko believes that to ensure security in the banking sector, to prevent damage to banking institutions, and for the bank to work effectively, the following measures should be taken: prevention of offenses and criminal encroachments on property and employees of the bank, prompt response by structural bank elements to emerging threats and negative trends in the development of external and internal circumstances, timely identification of real and potential threats to the bank, taking measures to eliminate them, identifying internal and external causes and conditions that may contribute to material and other damages suffered by the bank, its employees and customers, education and training of personnel in security, preservation and efficient use of financial, material and information resources of the bank (Goralko, 2011).

In addition to statistics, the SFMS annual reports contain plans for the current years, which are aimed at minimizing legalization (laundering) of criminal proceeds, terrorism financing and proliferation. They include the following measures:

1) improving the interaction of public authorities that are part of the national system for preventing and counteracting legalization (laundering) of criminal funds, terrorism financing and proliferation;
2) improving legislative provisions on the prevention and counteraction of the legalization (laundering) of criminal funds, terrorism financing and proliferation;

3) ensuring the functioning and development of a unified information system in the field of preventing and counteracting the legalization (laundering) of criminal funds, terrorism financing and proliferation;

4) international cooperation to counteract the legalization (laundering) of criminal funds, terrorism financing of and proliferation.

In terms of crime prevention in banking, the Ministry of Finance of Ukraine is focusing on combating crimes against the interests of the state in the financial and related fields. To do this, it is planned to create a Financial Investigation Bureau, which should become a tool for the detection, termination, disclosure and preliminary investigation of crimes, including in the banking sector. The Financial Investigation Bureau is planned to become a new civilian agency responsible for investigating financial crimes against the state, which will report to the Ministry of Finance instead of the tax police. Since the draft law on the Financial Investigation Bureau requires review, then - after filling in the identified gaps and adopting the law this agency will be directly involved in counteraction to crime in the Ukrainian banking sector (Sudebno-yuridicheskaya gazeta, 2019).

Reforming the state-owned banks can be a step towards reducing the risk of crime in the banking sector. The analytical work carried out by the Ministry of Finance of Ukraine is aimed at identifying systemic factors contributing to economic crime. Suggestions and recommendations arising from such an analysis are taken as the basis for the development of state policy with the aim of effectively preventing crime in the banking sector.

The National Commission for State Regulation of Financial Services Markets is a state collegial body that reports to the President of Ukraine and to the Parliament of Ukraine. Commission officials are vested with certain administrative and jurisdictional powers to prevent and respond to violations of the law on combating money laundering by offi- 
cials of the relevant primary financial monitoring bodies. There is also some interaction between the National Financial Services Commission and the Financial Intelligence Unit, since the intervention of the financial intelligence service is an important prerequisite for the effectiveness, consistency, comprehensiveness and soundness of anti-money laundering measures.

The NBU Public Council acts in accordance with the Regulations on the NBU Public Council No. 335 dated June 5, 2014 approved by the NBU Board of Directors. The NBU Public Council is a permanent collegial advisory body created for the effective interaction of the NBU and the public and protection of bank customers' rights and interests. The main tasks of the Public Council include, inter alia: developing proposals on implementation of effective mechanisms for protecting rights and legal interests of bank depositors and creditors; cooperation with the NBU in preparing and conducting public discussions on issues related to protecting bank customers' interests and rights; preparing draft regulations on the protection of rights and interests of bank customers; considering problematic issues related to the protection of rights and interests of bank customers and proposals for their elimination.

In accordance with the Agreement on the General Principles of Cooperation between these bodies of state financial monitoring, these parties, within their competence, take all measures of cooperation to prevent and combat legalization (laundering) of criminal funds and related criminal activities, as well as financing terrorism. At the same time, the parties, within their competence, in accordance with the law and based on this Agreement, send (by mutual agreement) their representatives to participate in joint events, create working groups to prepare and conduct joint events, exchange experience in this area, including through meetings, seminars and conferences, constantly exchange statistical, reference and analytical materials, methodological recommendations of mutual interest (except for information on the private life of citizens) to improve the personnel skills, etc.

The National Bank of Ukraine is a special central government body, the legal status, organization principles, tasks and powers of which are determined by the provisions of the Constitution of Ukraine, the Law of Ukraine On the National Bank of Ukraine and other laws of Ukraine. It should be noted that this bank regulates the activities of commercial banks in Ukraine. For example, according to the results of the audit conducted on March 1, 2019, the National Bank applied executive actions to Megabank and Commercial Bank Land Capital for violating the legislation in the field of financial monitoring. In particular, Megabank was charged a fine amounting to UAH 6,200,000.00 for carrying out risky activities in the field of financial monitoring, as an enforcement measure. This activity is reflected in the financial transactions carried out by the bank, namely in granting loans to a group of non-corporate bank customers in the amount of UAH 211.8 million. The origin of these funds allowed them to be converted into cash.

At the same time, a written warning was given to the Commercial Bank Land Capital as an executive action for violating the registration of financial transactions that are subject to mandatory financial monitoring, failure to identify financial transactions that are subject to mandatory financial monitoring, untimely provision of information to a special authority in cases stipulated by law (NBU, 2019).

The NBU develops special recommendations for payment card holders that help to mitigate the risk of losses in cashless payments for goods and services (also via the Internet) and in transactions using a payment card in ATMs. These recommendations include information on using ATMs, cashless payments and online transactions, as well as closing a current account. In particular, to minimize losses when using payment cards, the NBU recommends that you carefully follow the rules for storing and using a payment card, as well as avoid mechanical damage to the card and exposure to sunlight and moisture. Moreover, keeping a payment card near your mobile phone, magnetic or metal devices and near metal objects will adversely affect its quality.

The NBU also emphasizes that it is not recommended to provide payment card data through open channels of information exchange, namely e-mail, SMS, social networks, chats, etc. It is rec- 
ommended to have your payment card number and contact phone number of the issuing bank on other media (e.g., laptop, mobile phone, personal computer, etc.), but never store it with your PIN code. According to the NBU recommendations, activating the electronic notification service and setting a daily limit on the number of transactions and certain amounts using a payment card will help prevent illegal actions with a payment card (NBU, Recommendations for cardholders, 2019).

Banking institutions are important or even key actors in the fight against crime in the banking sector. According to the law, they are obliged to develop and take measures to prevent illegal encroachments on their infrastructure and property (storage protection, cash transactions, media, identification of unscrupulous partners, personnel protection, etc.). Strict control in credit institutions is the main measure to combat fraud.

Effective fight against crime in the banking sector involves the creation of an anti-abuse system that includes training credit departments on fraud prevention, introducing reliable information and technological equipment for the bank's security service, organizing close cooperation between representatives of the banking sector and law enforcement agencies, and introducing a unified customer database of relevant institutions.

The premises of banking institutions in the organizational plan should be located in such a way as to provide convenient routes for customers and favorable conditions for their servicing. Any possible intersections of customer movement and the transportation of cash and other valuables should be excluded. The ability to monitor cash and other valuables and the work of bank employees by clients and bystanders should be excluded. Signs of such opportunities should be used by security services of banking institutions for prevention purposes (Klochko \& Myslyvyy, 2014).

Among entities involved in combating banking crime, security services of banking institutions are of particular importance. Their main functions include: an audit of potential bank customers (borrowers) to see whether negative information is available that can adversely affect the approval of loans under various lending programs; organization and implementation of measures to protect the economic interests of a banking institution, as well as its structural units from external and internal threats; identification and suppression of criminal activity of bank employees who abuse their official position to the detriment of the economic interests of the banking institution; $\mathrm{CO}_{-}$ operation with law enforcement agencies, security services of partner banks to ensure the safety of banking activities, as well as other functions aimed at combating crime in the banking sector.

The main steps to counteract and prevent banking crimes should be implemented by the bank, in particular, its manager, who is responsible for monitoring the activities of the bank's structural units. One of such units is the credit (lending) department, the roles and responsibilities of which provide for pre-contract verification of potential borrowers, including: credit interview, customer support at the stage of loan consideration, preliminary approval of loan conditions, determining a potential borrower's solvency and assessing its financial status according to the established methodology, checking balances and other accounting documents provided by the client, analysis of the quality and completeness of the information provided by a client, economic evaluation of the potential borrower's economic activity (its effectiveness, customer competitiveness, position in the industry or fields of activity, availability of assets and liabilities of a borrower, etc.), submission of the loan project for consideration by the credit committee.

Possibilities of committing crime in the banking sector in the traditional way are significantly hampered by preventive measures such as photographing a potential client using a webcam while making a card or applying for a loan.

Finaheiev emphasizes the need for interaction between banking security services and operational units of law enforcement agencies and notes that the interaction of these actors in their fight against crimes in banking is regulated by law. This process is a set of measures for the efficient use of available forces, means and methods of criminal intelligence and the procedural nature and consolidation of their results. Taking these measures will significantly improve the interaction between 
the operational units and security services of the bank in combating banking crimes. The main objectives of banking supervision are to ensure the safety of the banking system and its financial stability, protect the interests of depositors and creditors, and regulate banking activities in order to comply with its current legislation. The organization of interaction during inspections by banking supervisory authorities and law enforcement agencies (Ministry of Internal Affairs of Ukraine, Security Service of Ukraine, and Prosecutor General's Office) allows identifying the facts of certain crimes in banking, such as financial fraud, and preventing legalization (laundering) of proceeds of crime through the banking system both nationally and internationally. This interaction allows identifying crimes in preparation stages (Finaheiev, 2016).

The bank's organizational structure is determined by the structure of its management bodies, as well as the structure of the services and units of the bank. Therefore, the subjects of combating banking crime at the level of a banking institution include: bank management and other officials, the credit unit of the bank, which analyzes primary documents provided by the potential borrower, checks the borrower, processes the loan and takes other measures; legal department of the bank, which analyzes the possibility of concluding an agreement and fulfilling borrower's obligations to the bank from a legal position; bank security service, whose roles and responsibilities include the immediate prevention of crimes; the bank's property and property rights department, which is responsible for evaluating and comprehensively checking collateral, technical specialists and those responsible for using computer equipment and for information security in the bank.

According to Herasymov, international institutional cooperation is necessary to combine the efforts of actors authorized to carry out activities aimed at combating banking crime by identifying, investigating, prosecuting, restoring violated rights, as well as developing tactics and strategies for combating crime, administrative, scientific, technical and personnel support (Herasymov, 2018). International institutions are social institutions operating at the level of the international system. Acting as the regulator of international relations, each international institution, within its competence, creates its own international political regime. For example, with the assistance of the European Bank for Reconstruction and Development, the Council of Europe, the European Commission, the Eurasian Anti-Crime Legislation and Terrorism Financing Group (EAG), the World Bank, the International Monetary Fund (IMF), the Organization for Security and Co-operation in Europe (OSCE), Organization for Economic Co-operation and Development (OECD), in conjunction with the State Financial Monitoring Service of Ukraine, an international institution organizes and conducts international seminars, conferences on crime prevention in various areas, in particular, corruption schemes in the banking institutions are an urgent issue now. With the participation of the international experts who are representatives of financial intelligence units of other countries, law enforcement agencies, state regulators and judges, the strategies are being discussed to identify criminal actions of corrupt banks.

Citizens as bank clients play a special role in combating crime in the Ukrainian banking sector. In particular, counteraction to banking crimes should be encouraged with the help of basic principles, such as self-protection, which is part of psychological defense of one's consciousness (a kind of internal prevention) from the influence of external aggressive factors and the implementation of certain, sometimes simple, algorithms of actions that can protect a bank client from loss of money and other related negative effects.

Internal prevention primarily leads to people's ability to withstand the psychoactivity of outsiders and to overcome adverse or extreme situations with minimal psychological trauma. Today, criminals use many ways to capture people's money using electronic means of payment or payment devices. Many of these methods of committing crimes stem from the psychological manipulation skills of offenders using intimidation and psychological pressure. Elderly people, women and adolescents are among the most vulnerable to this influence. Due to psychological manipulations they follow all the instructions of the criminals, disclose their personal data, payment card details, codes/passwords. 
At the psychological level, a person's ability to withstand external threats aimed at manipulating consciousness and receiving money should manifest itself as a concentration of his/her own efforts to independently overcome the situation. Such concentration should be a deliberate decision-making process, not a quick, impulsive response.

In this context, Skazko adds that improving the legal framework related to enhancing the security of banking operations is an extremely important aspect of reducing the risks of illegal actions against banking institutions. Two areas are of paramount importance: the security of transactions with valuables in banks, and the collection and transportation of valuables (Skazko, 2014).

Without limiting the above, both non-corporate bank clients and employees of banking institutions are required to notify law enforcement agencies of any cases of fraud and other banking crimes. The implementation of these measures by citizens will contribute to the effective counteraction and prevention of crimes in the banking business in Ukraine.

\section{DISCUSSION}

Combating crime in the banking sector is a strategic national task, in which not only practitioners, but also leading scientists in economics, criminal law and criminology should participate. They must be able to analyze the development trends in the country's banking system, identify risks that negatively affect its stable functioning and propose ways to improve the system of combating crime in banking.

Forms of statistical reporting on crime in the banking sector in Ukraine need to be improved. In particular, they should contain specific information both on types of banking crimes and persons who committed them (sociodemographic character- istics, roles and status, etc.) In this sense, positive experience of foreign countries is significant for Ukraine. The USA has quite positive experience in the fight against banking crime. Besides, the United States Code of 1962 contains many criminal legal provisions establishing liability for banking crimes. For example, the 2018 report of the Federal Bureau of Investigation in Washington Banking Crime Statistics (FBI, n.d.), contains detailed information on the number of reported crimes in the banking sector over a specified period of time; criminal legal rules establishing liability for banking crimes; types of banking institutions; information about the criminal identity (containing general characteristics and specific qualities); information about the day of the week and time of the crime; type of office of a financial institution (head office, branch, etc.); safety devices used by the affected institutions; safety devices used for crime; safety devices that have worked; consequences of the crimes, etc.

Along with the work of the NBU Public Council, it is proposed to create regional public councils for cooperation between consumers and banking institutions at the regional levels and define their key tasks, which should be aimed at developing effective mechanisms to protect bank depositors' and creditors' rights and legal interests, as well as to counter criminalization of banking activities.

Crime prevention in banking requires consolidated efforts by all relevant entities, in particular law enforcement bodies, executive authorities, public authorities, state collegial bodies, NBU's territorial departments, Ukrainian banks and their affiliates, international institutions and non-corporate bank customers. At the state level, it is necessary to develop and adopt a unified Security Strategy for Banks and Lending Institutions, which would determine the range of entities of combating crime in banking in Ukraine, the main directions of their preventive activity and ways of their interaction aimed at protecting banking institutions from unlawful actions.

\section{CONCLUSION}

An analysis of provisions, scientific articles and functions of some institutions that ensure stability of the Ukrainian banking system has led to the conclusion about the need to improve the system of combating crime in the Ukrainian banking sector. Banking system is an important element of 
ongoing economic reforms in Ukraine. Ukraine's way towards European integration has caused an intensive development of the banking sector (Klochko, Kurilo, \& Zapara, 2019). Therefore, it is necessary to strengthen the protection of the banking sector in Ukraine, which is currently neither sufficient nor commensurate with European countries. Obviously, the current protection of the banking sector in Ukraine does not correspond to the high demand for banking services among the population. The imperfect system of combating banking crimes is confirmed by selective statistical indicators of crimes committed in recent years, and the emergence of new types of abuse along with the development of banking technologies. It can be stated that today the system of combating crime in banking in Ukraine does not exist as such. The entities of combating crime in the banking sector act as single entities; they are uncoordinated and even chaotic. The entities studied operate through selective performance of their functions exclusively within the framework of their authorities, and such performance is not coordinated with other subjects. This leads to the lack of a clear algorithm of actions to be taken in case of an emergency as a result of criminal offenses or direct damage caused by them.

To ensure the Ukrainian banking system stability, effective counteraction to bank crime should be facilitated and general measures should be taken; they may include reforms in the economy aimed at improving living standards and quality of life of the population. Combating crime in the banking sector is a complex of various preventive measures. This activity is deliberate in nature, and, given the determinants of crime, contributes to the activation of anti-criminogenic factors and has a neutralizing impact on criminogenic factors. Obviously, Ukraine has all the necessary resources to ensure the stable functioning of the banking system. This requires the creation of a clear and effective mechanism for the interaction of crime counteraction actors in the banking sector, development of appropriate action algorithms, the elimination of legislative gaps, chaotic, obscure and contradictory forms of statistical reporting, and the strengthening of functions of some local entities combating crime in the banking sector.

\section{ACKNOWLEDGMENT}

The article was prepared as part of a project for young scientists of Ukraine in 2017 (state registration number - 0117 U 006531), Improving the Legislation of Ukraine Regarding the Protection of Banking Activities in the Context of European Integration: Economic and Legal Aspect, by Alyona M. Klochko, Ph.D. (Law), Sumy National Agrarian University, Head of the Chair of International Relations.

\section{AUTHOR CONTRIBUTIONS}

Conceptualization: Alyona Klochko.

Data curation: Mykola Logvinenko.

Formal analysis: Alyona Klochko, Mykola Kurylo, Oksana Kvasha, Mykola Logvinenko.

Funding acquisition: Alyona Klochko, Zoia Zahynei.

Investigation: Alyona Klochko, Mykola Kurylo, Oksana Kvasha, Zoia Zahynei.

Methodology: Alyona Klochko.

Project administration: Mykola Kurylo.

Resources: Oksana Kvasha, Mykola Logvinenko.

Writing - original draft: Alyona Klochko.

Writing - review \& editing: Mykola Kurylo, Zoia Zahynei, Mykola Logvinenko. 


\section{REFERENCES}

1. European Commission. (2016). European Semester: Thematic factsheet - Banking sector and financial stability - 2017. Retrieved from https://ec.europa. eu/info/business-economy-euro/ economic-and-fiscal-policy-coordination/eu-economic-governance-monitoring-preventioncorrection/european-semester/ thematic-factsheets/financialstability_en

2. FBI. (n.d.). Bank Crime Statistics (Bank Crime Statistics from Federally Insured Financial Institutions from 2003 to Present). Retrieved from https://www.fbi. gov/resources/library/bank-crimestatistics

3. Finaheiev, V. A. (2016). Vzaiemodiia operatyvnykh pidrozdiliv zi sluzhbamy bankivskoi bezpeky u protydii shakhraistvu $\mathrm{v}$ sferi kredytuvannia [Interaction of operating divisions and banking security services in counteracting lending fraud]. Yurydychnyi chasopys Natsionalnoi akademii vnutrishnikh sprav - Law Journal of the National Academy of Internal Affairs, 11(1), 252-262. (In Ukrainian). Retrieved from https://ojs.naiau.kiev.ua/index. php/lawjournal/article/view/556

4. Goralko, O. V. (2011). Finansova bezpeka bankiv u systemi zabezpechennia finansovoi bezpeky derzhavy [Financial security of banks in the system of financial security of the state]. Naukovyi visnyk Lvivskoho derzhavnoho universytetu vnutrishnikh sprav - Bulletin of the Lviv State University of Internal Affairs, 2, 328-337. (In Ukrainian). Retrieved from http://nbuv.gov.ua/ UJRN/Nvldu_e_2011_2_39

5. Hartmann, P., Straetmans, S., \& De Vries, C. G. (2005). Banking System Stability: A Cross-Atlantic Perspective (NBER Working Paper No. 11698). Retrieved from https://www.nber.org/papers/ w11698

6. Herasymov, O. V. (2018). Banking Crime Counteraction (Ph.D. Thesis). Kharkiv: V. N. Karazin
Kharkiv National University. (In

Ukrainian). Retrieved from http://

dspace.univer.kharkov.ua/bit-

stream/123456789/14557/2/aref-

Herasymov.pdf

7. Hong Kong Monetary Authority (HKMA). (2003). Banking Supervision in Hong Kong. Retrieved from https://www.legco. gov.hk/yr06-07/english/panels/fa/ papers/facb1-657-2-e.pdf

8. Kashpur, L. M. (2018).

Counteraction of Incomes Legalization Which Are Illegally Received. Investytsii: Praktyka ta Dosvid - Investment: Practice and Experience, 3, 103-106. (In Ukrainian). Retrieved from http://www.investplan.com. ua/?op $=1 \& z=5925 \& \mathrm{i}=20$

9. Klochko A. N., Kurilo N. P., \& Zapara S. I. (2017). K voprosu ugolovno-pravovoy okhrany sfery bankovskoy deyatelnosti Ukrainy [Criminal law protection of banking activities in Ukraine]. Vserossiyskiy kriminologicheskiy zhurnal - Russian Journal of Criminology, 11(4), 833-843. (In Russian). Retrieved from http://cj.bgu.ru/reader/article. aspx?id=21877

10. Klochko, A. M, \& Myslyvyy, V. A. (2014). Rozbiini napady na bankivski ustanovy: kryminolohichna kharakterystyka ta zapobihannia [Bank robberies: criminological characteristics and prevention] (253 p.). Sumy: SSU. (In Ukrainian).

11. Klochko, A. M, Kurilo, N. P., Kurilo, S., \& Zapara, S. I. (2019). Criminal Legal Protection of Banking in Ukraine and at the International Level. Journal of Engineering and Applied Sciences, 14(1), 29-35. Retrieved from http://dx.doi.org.ua/10.36478/ jeasci.2019.29.35

12. Kovalenko, A. V. (2016). Politsiia yak subiekt diialnosti shchodo zapobihannia zlochynnosti [Police as a crime prevention entity]. Naukovyi visnyk Mizhnarodnoho humanitarnoho universytetu - Scientific Bulletin of the International Humanities

University, 24, 110-113. (In

Ukrainian). Retrieved from http://

www.vestnik-pravo.mgu.od.ua/ archive/juspradenc24/30.pdf

13. Kurylo, M., Klochko, A., Timchenko, G., \& Gulyk, A. (2017). Banking in Ukraine as an object of criminal and legal protection. Banks and Bank Systems, 12(4), 114-120. http://doi. org.ua/10.21511/bbs.12(4).2017.11

14. Likhnovitsky, Ya. O. (2014). Prokuratura yak subiekt protydii zlochynnosti [The Prosecutor's Office as a subject of combating crime]. Porivnialno-analitychne pravo - Comparative Analytical Law, 7, 182-185. (In Ukrainian). Retrieved from http://www.pap. in.ua/7_2014/54.pdf

15. Liovochkin, S. V., Oparin, V. M., \& Fedosov, V. M. (2011). Superechnosti finansovoi teorii i praktyky v konteksti ekonomichnoho rozvytku [Contradictions of financial theory and practice in the context of economic development]. Finansy Ukrainy - Finance of Ukraine, 6, 13. (In Ukrainian).

16. Prosecutor's Office of Volyn region. (2018). Volyn Prosecutor's Office commenced criminal proceedings on the misappropriation of more than UAH 100 million by Zakhidincombank officials. Retrieved from http://vol. gp.gov.ua/ua/news.html? $\mathrm{m}=$ publications\&_c=view\&_ $\mathrm{t}=\mathrm{rec} \& \mathrm{id}=14500$

17. Security Service of Ukraine. (2019) Official web-site. Retrieved from https://ssu.gov.ua/en/

18. Skazko, Yu. A. (2014). Protydiia zlochynnosti u sferi napadiv na bankivski ustanovy ta inkasatoriv: zarubizhnyi dosvid ta implementatsiia yoho v Ukraini [Crime counteraction to attacks on banking institutions and collectors: foreign experience and its implementation in Ukraine]. Yurydychna nauka - Legal Science, 6, 67-75. (In Ukrainian). Retrieved from http://nbuv.gov.ua/ UJRN/jnn_2014_6_10 
19. State Bureau of Investigations of Ukraine. (n.d.). Derzhavne biuro rozsliduvan. Official web-site. (In Ukrainian). Retrieved from: https://dbr.gov.ua/

20. State Financial Monitoring Service of Ukraine (SFMS) (2009). Typolohii lehalizatsii (vidmyvannia) dokhodiv, oderzhanykh zlochynnym shliakhom [Typologies of Legalization (laundering) of Proceeds from Crime]. Retrieved from https://www.sdfm.gov.ua/ assets/userfiles/411/\%D0\%A2\%D 0\%B8\%D0\%BF\%D0\%BE\%D0\%B B\%D0\%BE\%D0\%B3\%20\%D0\%9 4\%D0\%A1\%D0\%A4\%D0\%9C\%D 0\%A3/2009\%2012\%2029 gotivka. pdf

21. State Financial Monitoring Service of Ukraine (SFMS). (n.d.). Zapobihannia koruptsii [Prevention of corruption]. Official web-site. (In Ukrainian). Retrieved from https://www.sdfm. gov.ua/pages/pro-sluzhbu/zapobigannja-korupci

22. Sudebno-yuridicheskaya gazeta. (2019, September 10). Zakonoproekt "Pro Biuro finansovykh rozsliduvan" proholosuiut u pershomu chytanni $z$ nedolikamy [The bill on the Bureau of Financial Investigation is voted in the first reading with flaws]. Retrieved from https://sud. ua/ru/news/publication/149829- zakonoproekt-pro-byuro-finansovikh-rozsliduvan-progolosuyut-upershomu-chitanni-z-nedolikami

23. The National Bank of Ukraine (NBU). (2011). Postanova Pravlinnia NBU 20.06.2011 No. 197 "Pro zatverdzhennia polozhennia pro poriadok orhanizatsii ta provedennia perevirok $z$ pytan zapobihannia ta protydii lehalizatsii (vidmyvanniu) dokhodiv, oderzhanykh zlochynnym shliakhom, finansuvanniu teroryzmu ta finansuvanniu rozpovsiudzhennia zbroi masovoho znyshchennia" [Resolution of the Board of the NBU 20.06.2011 No. 197 "On approval of the Regulations on the Procedure for Organizing and Conducting Checks on the Prevention and Counteraction of the Legalization (Laundering) of Proceeds of Crime, Financing Terrorism and Financing the Proliferation of Weapons of Mass Destruction"]. (In Ukrainian). Retrieved from https://zakon.rada. gov.ua/laws/show/z0852-11

24. The National Bank of Ukraine (NBU). (2019, January 31). Natsionalnyi bank $u$ sichni zastosuvav do triokh bankiv zakhody vplyvu za porushennia zakonodavstva u sferi finmonitorynhu [In January, National Bank applied impact measures to three banks for violating legislation in financial monitoring]. Retrieved from https://bank.gov.ua/news/all/ natsionalniy-bank-u-sichni-zastosuvav-do-troh-bankiv-zahodivplivu-za-porushennya-zakonodavstva-u-sferi-finmonitoringu

25. The National Bank of Ukraine (NBU). (n.d.). Rekomendatsii Derzhateliam Platizhnykh Kartok [Recommendations for payment card holders]. (In Ukrainian). Retrieved from https://bank.gov. ua/admin_uploads/article/CARD_ recommendations.pdf

26. Verkhovna Rada of Ukraine. (2001). Kryminalnyi kodeks Ukrainy [The Criminal Code of Ukraine]. Vidomosti Verkhovnoi Rady Ukrainy, 25-26. Retrieved from https://zakon.rada.gov.ua/ laws/show/en/2341-14

27. Verkhovna Rada of Ukraine. (2014). Zakon Ukrainy "Pro zapobihannia koruptsii” [Law of Ukraine On the Prevention of Corruption]. Vidomosti Verkhovnoi Rady, 49, st. 2056. Retrieved from https://zakon.rada. gov.ua/laws/show/1700-18

28. Verkhovna Rada of Ukraine. (2015). Zakon Ukrainy "Pro prokuraturu" [Law of Ukraine On Prosecution]. Retrieved from https://zakon.rada.gov.ua/laws/ show/1697-18?lang=en 